\title{
China Studies in Germany
}

\author{
LI Xuetao*
}

\begin{abstract}
China studies in Germany has undergone great changes since the 1960s. Influenced by burgeoning area studies in the United States, German scholarship shifted from traditional philological studies focused on translating and interpreting Chinese classics to practical studies of modern Chinese politics, economy, law, etc. Hence, there was also a shift in research methodologies to those of the social sciences. However, this shift, significant as it is, can never replace traditional Sinological studies aimed at Chinese history and classics. This paper uses Chinese history as an example to explore the development of German academic Sinology. It points out that research in traditional Sinology, as well as in modern China studies, no longer focuses on a particular discipline, but rather follows the trend toward interdisciplinary, comprehensive research. Hence we can expect that China studies will become increasingly decentralized and interactive in the future development of the field.
\end{abstract}

Keywords: German Sinology, German China studies, Chinese history in Germany

I

The notion of a paradigm shift signifies a change in the intellectual climate of an age to a deeper level. Progress in an age inevitably gives rise to new theories incompatible with the old paradigm. As a result, there is movement to a new set of standards, which eventually results in a paradigm shift. The paradigm shift in research on China is an inevitable result of changes in the thought and circumstances of society from one age to the next. German research on China and its traditions of knowledge and culture was at first carried out in helter-skelter fashion in areas such as translation and interpretation, traditional China and cultural China, contemporary China and actual China, and Chinese spiritual traditions and cultural traditions. In German research on China, there was no translation era distinct from an interpretation

* Li Xuetao 李雪涛 is director of the Institute for Global History at Beijing Foreign Studies University. 
era, nor was there a Sinology period clearly separate from a China-studies period. From the beginning, these different focuses were woven together. German Sinology began with the founding of the practically motivated Seminars for Oriental Languages at Humboldt University of Berlin in 1887, and many of the early Sinologists started out as practically minded missionaries and diplomats. In fact, the history of Sinology is a history of paradigm changes. By investigating the individual cases of paradigm changes, we can understand the basic German, and also Western, assumptions for knowing about China.

In fact, in addition to concern with its own tradition and development, German Sinology might also react to changes in Chinese society. Early on, in the 1950s, the Federal Republic of Germany began establishing Chinese research institutions outside of the university system. For instance, in 1956 West Germany's Foreign Office and the city of Hamburg together established the Institut für Asienkunde (Institute of Asian Studies). ${ }^{1}$ Its most important task was research on actual political issues in the Chinese mainland, and it also published the journal China aktuell (now published as the Journal of Current Chinese Affairs). In 1959 the Foreign Office revived the Seminars for Oriental Languages, established in Berlin in 1887, at the University of Bonn, in order to train specialists in East Asian languages, including Chinese. And in 1967 the German Association for Asian Studies was established in the West German capital of Bonn with support from the Volkswagen Foundation and the Ford Foundation. Its mission was to expand German fields of study from Sinology and Japanology to such fields as politics, economics, and law; to promote interaction and cooperation between Germany and East Asia; to consult on research on contemporary East Asia; etc.

Most academics recently retired from German departments of Sinology participated in the 1968 European student movement, and most were leftists. Hence, they have been influenced by the Chinese revolutionary thought and Mao Zedong thought current at the time. As the 1968 student movement deconstructed traditional Sinological research at the time, students called for relevant studies of China's revolutionary progress. Because study of the classics using simple philological methods obviously could not be adapted to the study of Mao Zedong thought, it became necessary to introduce the methods of the social sciences. The East Asian Department of the Free University of Berlin initiated relevant innovations, and Sinology departments at other German universities followed suit. China's reform and opening up in

1 See Fünfzig Jahre Institut für Asienkunde in Hamburg (Fifty Years of the Institute of Asian Studies in Hamburg), edited by Hans-Wilm Schütte (Hamburg: Instituts für Asienkunde, 2006). 
the late 1970s opened up China's market to Western Europe and West Germany in particular. The hope was that the China market would give Germany huge economic profits, but the Sinology departments of Germany's universities were in no position to train the required talent. Hence, many German universities began to institute dual majors of China studies and economics. One of the earliest was the University of Tübingen, which introduced programs combining different fields, including the combination of political economics (Volkswirtschaftslehre) and East Asian cultural studies. Recently, dual programs are increasingly popular. Many Sinology departments, in addition to offering traditional majors (called "Sinology I"), have added China study programs (called "Sinology II"), which can be combined with such popular majors as political economics or business administration (Betriebswirtschaftslehre). This too is part of the effort to meet the demand for China specialists.

The challenges and issues presently encountered by research on China cannot be solved by the pure Sinology of the past. Hence, China studies (Chinawissenschaften) has arisen of necessity. Sinology and China studies are different but connected types of study. Classical studies, philology, and historical studies are still needed to understand the culture and history of China, and they will never disappear, but at the same time, they are considered exotic subjects. In contrast, in China studies, which concerns real issues in Chinese society, the focus is on various areas of Chinese society, such as politics, economics, military affairs, diplomacy, law, and medical care. The methodologies used come from various social sciences and even natural sciences.

It is difficult to evaluate the trend toward China studies in research on China. A century ago, many people never even heard of the field of Sinology, but now China studies has become a popular subject pursued by quite a few students. One scholar thinks that the transition from Sinology to China studies in the United States was in fact a transition from an exotic subject to a popular subject: "John K. Fairbank moved the core of research on China from premodern times to the modern and contemporary age, and applied the methods of the social sciences. At the same time he essentially retreated to the shortcomings of traditional European Sinology prior to Edouard Chavannes, even though his treatment seemed more practical."2 "The problem that Fairbank faced was not so much to advance the field of Sinology, as he said,

2 Sang Bing 桑兵, Guoxue yu Hanxue: Jindai Zhong-wai xuejie jiaowang lu 国学与汉 学: 近代中外学界交往录 (National Studies and Sinology: A Record of Modern Contact between Chinese and Foreign Academic Circles) (Hangzhou: Zhejiang Renmin Chubanshe, 1999), p.15. 
but to transform a calling for a select few into a program for the more ordinary many. The many graduates of the standardized program are an indication of the success and practical value of his method." 3 Thus, in contrast to the humanities scholars trained in Sinology programs, the students trained in China-studies programs studied a greater variety of subjects at a greater variety of levels. As a matter of fact, under Otto Franke (1863-1946), first chair of the Seminars for Oriental Languages, Stefan Balázs in 1932 wrote a doctoral dissertation titled "Contributions to the Economic History of the Tang Dynasty (618-906)," in which he used Max Weber's socioeconomic methods to study the economy of the Tang dynasty. ${ }^{4}$ In his dissertation, Balázs explained the development of Chinese society in terms of China's bureaucratic system, and in examining the structure of Chinese society, he pointed out that the relationship between the scholar-official class in Chinese society and the system for occupying positions of power was a complex one. In short, in analyzing the history of China's economy from Sui and Tang times, Balázs took Weber's methodology as his paradigm to investigate the universal aspects and peculiarities in changes in Chinese society. Without doubt, this was a declaration of revolt against the Sinology of the time, with its heavy emphasis on philological studies of the classics.

China studies in the United States is a component of its area studies, supporting its strategy of global domination. Since U.S. China studies received money from the U.S. government and various foundations during the cold war, this money gave its China studies the flavor of a countermeasure, made such studies seem ideologically motivated, and put pressure on programs to achieve noticeable results in a short period of time. As a result, group collaborative teamwork became the norm. This mode of operation can achieve quick results in such social-scientific fields as political science, sociology, economics, and anthropology, and in the compilation of large dictionaries, but truly creative advances in the humanities are often the result of individual labors. Moreover, research programs initiated by the government often become a means for particular ends. Under these circumstances, even historical research could be affected by practical concerns. As a matter of fact, China studies, which make use of methodologies of the social sciences, can never replace Sinology, which focuses on the study of classics and history. For this reason, European Sinologists are critical of U.S. China studies for seeking to adopt new methodologies and engage in new theoret-

3 Sang Bing 1999, p.17.

4 Stefan Balázs, "Beiträge zur Wirtschaftsgeschichte der T’ang-Zeit (618-906)" (Contributions to the Economic History of the Tang Dynasty, 618-906), dissertation, Seminars for Oriental Languages at the Friedrich Wilhelm University in Berlin, 1932. Reprinted by de Gruyter. 
ical interpretations while neglecting the close reading of texts.

In the final analysis, the situation in the West promoted in its China studies a problematique that sought to further Western development. Edward Said (1935-2003) thought that it is inappropriate for Western scholars to engage in research of the Other for their own needs. Later scholars have thought that Western scholars and East Asian scholars alike should engage in equal research and comparison, that the West is not the only center of worthwhile research.

\section{II}

Already in the latter half of the nineteenth century, experts in particular fields entered China to do research in their fields of expertise, the most typical example being Ferdinand von Richthofen (1833-1905), the wellknown geologist, cartographer, and explorer. From 1868 to 1872 Richthofen entered China seven times on exploratory journeys, and during this period, he pointed out the location of Lop Nur, the salt lake bed by the Loulan ruins. In fact, the English name of the Qilian Mountains, at the southern edge of the Gansu Corridor, bears his name: Richthofen Range. Using materials researched while he was in China, Richthofen wrote China: Ergebnisse eigener Reisen und darauf gegründeter Studien (China: Results of One's Own Travel and Studies Stemming Therefrom), a five volume work with two collections of maps. In the first volume, published in 1877, the term "Silk Road" (Seidenstraße) appeared for the first time. After he returned from China to Germany in 1872, he served, from 1873 to 1878 , as president of the Berlin Geographical Society. In 1875 he received an appointment as professor of geography at the University of Bonn, and in 1886 he moved to Humboldt University of Berlin. His most well-known student concerned with research on China was the Swedish explorer Sven Hedin (1865-1952). In many areas of geography, Richthofen is viewed as an important pioneer. Indeed, he has received praise from experts for his geological records and investigative results and writings. But German Sinologists regard him as a non-Sinological China hand. Though Otto Franke criticized Richthofen especially harshly, he also offered this impartial evaluation: "By the stir that Richthofen's work caused everywhere, one can hope that the major academic institutions turn their full attention to these vast new areas of research. Politics and science both in the same way point toward the Far East." 5 To be fair, Richthofen's work offers important revelations for comprehensively investigating and

5 Otto Franke, "Die sinologischen Studien in Deutschland" (Sinological Studies in Germany), in his Ostasiatische Neubildungen (A New History of East Asia) (Hamburg: Verlag von C. Boysen, 1911), p.361. 
understanding China's geography and typography. One cannot deny the appropriateness of his conclusions just because he was insufficiently proficient in Chinese and made mistakes in quoting from the Chinese.

From the latter half of the twentieth century on, every academic subject became increasingly specialized, and the field of Sinology was no exception. If German scholars were to insist on philological studies of the classics as found in traditional Sinology and make efforts to train only scholars versed in Chinese literature, history, and philosophy, German Sinology would probably lag behind the pace of development of China studies in the rest of the world. But departments of Sinology were hard pressed to accommodate the various fields of research on China. Already in the 1960s scholars were achieving significant results outside the field of Sinology, such as a group at the Free University of Berlin that conducted research on Chinese Mainland politics. The main member of this group was Jürgen Domes (1932-1999), professor of political science at the university and a right-wing anticommunist. ${ }^{6}$ Then, since China's reform and opening up in the late 1970s, this tendency became increasingly apparent, with more and more teachers in non-Sinological fields making significant contributions to research on China. For instance, Prof. Paul U. Unschuld (b.1943) was director of the Institute for the History of Medicine at Ludwig Maximilian University of Munich from 1986 to 2006 and later director of the Horst-Görtz Institute for the Theory, History, and Ethics of Chinese Life Sciences at Charité University Hospital in Berlin (founded with support from the Horst-Görtz Foundation). Prof. Thomas Heberer (b.1947), who studies China from the perspectives of ethnology and political science, has served as professor of political science and East Asian studies at the University of Duisburg-Essen since 1998. Robert Heuser, a legal scholar at the Institute of Contemporary China Studies at the University of Cologne, studies China's legal system and is active mostly in jurisprudence circles. Prof. Jürgen Osterhammel (b.1952) has taught at the University of Konstanz since 1999 and is a professor at the Institute of Modern and Contemporary History there. These scholars teaching in various disciplines have contributed to Sinology and China studies from core Western fields of study.

The important histories of China written by Sinologists all belong to

6 Jürgen Domes's works deal mainly with the history and circumstances of the Guomindang and the Communist Party, and include Politik und Herrschaft in Rotchina (Politics and Control in Red China) (Stuttgart, 1965), Vertagte Revolution: Über die Politik der Kuomintang von 1923 bis 1937 (Delayed Revolution: On the Policies of the Guomindang from 1923 to 1937) (Berlin, 1969), and Politische Landeskunde der Volksrepublik China (The Circumstantial Politics of the People's Republic of China) (Berlin, 1982). 
collections of world history. Johann Christoph Gatterer (1727-1799), founder of the eighteenth-century Göttingen school of history, devoted 345 pages to China in his Handbuch der Universalhistorie nach ihrem gesamten Umfange von Erschaffung der Welt bis zum Ursprunge der meisten heutigen Reiche und Staaten (Manual of Universal History, from the Creation of the World Up to the Origin of Most of Today's Empires and States, 1761-1764). Relying on historical materials from the Jesuits, Gatterer divided Chinese history into three epochs: (1) from the founding of China up to the fourth century BCE, (2) the fourth and third centuries BCE, and (3) from the second century BCE on, the epoch of increasing abundance and purpose. ${ }^{7}$ In 1910 August Conrady published his Geschichte Chinas (History of China) as part of the well-known three-volume work Ullsteins Weltgeschichte (Ullstein's World History). Conrady used the methodology of ethnology to thoroughly examine Chinese history up to and including the Qin dynasty (221-207 BCE). Another Sinologist of Leipzig, Eduard Erkes (1891-1958), published his Geschichte Chinas (History of China) in Berlin in 1948. The publisher was Volk and Wissen, a text publisher, and Erkes's Chinese history was but part of the publisher's complete set of world history. The Sinologists Herbert Franke (1914-2011) and Rolf Trauzettel (b.1930) wrote Das chinesische Kaiserreich (The Chinese Empire, 1968), which appeared as number 19 in the series Fischer Weltgeschichte (Fischer World History).

These German works on Chinese history are all considered part of world history. Though there are many such sets of world history, they all basically fall within three types. One type linearly traces human development along the line seen in Europe and ignores other patterns of development and other forms of civilization in the world. Another type simply piles up the histories of various regions one on top of another without drawing any connections or showing any reciprocal influences. And a third type focuses on historical phenomena in particular regions, ethnic groups, or cultures, making it difficult for the reader to gather a view of world history as a whole.

Jürgen Osterhammel was the first to really deal with modern China in the scope of world history. He emphasized that by breaking down national barriers, we can explore and understand history through broad mutual interactions and mutual influences, and that what is most important here is the mutual nature of the influences. His book Die Verwandlung der Welt: Eine Geschichte des 19. Jahrhunderts (The Transformation of the World: A History of the Nineteenth Century, 2009) does not simply lay out the history of countries of the nineteenth century, but seeks the origins of the present by

7 Johann Christoph Gatterer, Handbuch der Universalhistorie (Göttingen: Vandenhoeck, 1764), vol.1, pt.2, Einleitung, p.4. 
tracing back in time, and tries to show the reader how the nineteenth century caused the whole world to arrive at the present historical period. Osterhammel does not stand out for his grand narration of events, nor does he follow chronological order in narrating events. On the contrary, he is notable for taking the rich materials of world history to the present and dividing them into three different areas and then further dividing them into eighteen themes in order to create an accurate exposition. These motifs of world history include domains (such as time or space), problem areas (such as borders), surveys of changes in conditions (such as standards of living), processes (such as revolutions), structures (such as cities or nation-states), or the scope of the notion of production or reproduction (such as work or knowledge). By means of this methodology, one can avoid neglecting external-logic analyses of historical figures, anecdotes, and narrations. Osterhammel thinks that world history is a history of mutual influence in the global system. Even though he is a Sinologist, he clearly sees that the development of historiography based European history already cannot adequately explain European history in a self-contained way. Osterhammel's influence is clearly not limited to the field of Sinology. His works nearly always take on the perspective of world history. For this reason he received the prestigious Leibniz Prize. On July 17, 2014, on the occasion of the sixtieth birthday of Chancellor Angela Merkel (b.1954), Osterhammel gave a report on world history titled "Vergangenheiten: Über die Zeithorizonte der Geschichte" (Varieties of the Past: On the Time Horizons of History) before a thousand invited guests at the Konrad Adenauer House. China was, of course, an important part of the report.

\section{III}

Lucien Febvre (1878-1956), a well-known historian of the Annales School, noticed that a closed discipline at present has no value and no vitality. He wrote, "All discoveries are made not at the heart of each discipline, but at the borders, margins, and frontiers of disciplines, where they permeate one another." 8 John King Fairbank (1907-1991), in his autobiography where he describes his oral defense, wrote, "I learned how to be a Sinologist among historians, or to put it a little differently, how to be a historian among Sinologists. It is like being a Chinese bandit who always eludes capture: he establishes a base at the border of two provincial jurisdic-

8 Lucien Febvre, Combats pour l'histoire (Battles for History) (Paris: Armand Collin, 1953), p.30. Available at http://classiques.uqac.ca/classiques/febvre_lucien/ Combats_pour_lhistoire/febvre_combats_pour_histoire.pdf. 
tions, and when one side comes for him, he flees to the other side." 9 By conducting research at the junction between history and Sinology, Fairbank could forge new paths and become the reason that the United States embarked on China studies.

If we look at the present development of Sinology in Germany, we see that because power over culture and education resides at the state level, the development of Sinology departments is very uneven, and that research interests and teaching content depends on the interests and knowledge of particular professors. For example, after Wolfgang Kubin (b.1945) left the University of Bonn, the historian Ralph Kauz took his place, and the research emphasis at Bonn changed from Chinese literature and history of thought to Chinese history, and in particular to relations between China and Persia since the Yuan dynasty (1279-1368). The University of Hamburg focuses on ancient Chinese philosophy and modern Chinese history from the late Qing period. The University of Berlin emphasizes contemporary social-scientific research. Ludwig Maximilian University of Munich leans toward the history of Chinese thought and philosophy. The University of Erlangen-Nürnberg and Goethe University of Frankfurt offer excellent exchange programs for research in the history of Chinese science and ideas. And Heidelberg University has a outstanding research institute for research in the history of East Asian fine arts. This academic scene, compared with China studies in the United States, has both an advantage and a disadvantage: the advantage is that it allows greater academic freedom, and the disadvantage is that it discourages systematic development of a large-scale program in Sinology.

Nonetheless, Germany has made efforts to integrate European Sinology. For instance, in 1998 the Sinology Department of Heidelberg University, led by Rudolf Wagner (b.1941), established the European Center for Digital Resources in Chinese Studies. As a result, Sinology resources in Europe have become more integrated in such systems as the European Virtual OPAC for Chinese Studies, an online public-access catalog that includes the resources of important Sinology libraries in Austria, Germany, Switzerland, Belgium, Holland, France, England, and Scandinavia, as well as those of the German Union Catalogue.

Since 2003, the European Union has tried to introduce the Bologna Process, a set of uniform regulations, modeled on those in the United States, designed to gain recognition of bachelor's and master's course programs in

9 John King Fairbank 费正清, Fei Zhengqing zizhuan 费正清自传 (The Autobiography of John King Fairbank), (Tianjin: Tianjin Renmin Chubanshe, 1993), p.170. Translated from John King Fairbank, Chinabound: A Fifty-Year Memoir (New York: Harper and Row, 1982). 
Europe and the world at large. In recent years, these policy requirements have sparked continuous discussions in German Sinology circles and in Chinese academic circles. To take bachelor requirements in Sinology departments as an example, though students are required to acquire a level of proficiency in Chinese and learn a lot about Chinese culture in four terms, they cannot possibly accomplish all this.

Since the start of the twenty-first century, German Sinology has tended to become more specialized and to increasingly rely on social-scientific methodologies to carry out research on China. In 2006 the Institut für Asienkunde (Institute for Asian Studies) in Hamburg changed its name to German Institute of Global and Area Studies, and it changed its journal from a large-format journal of German and English papers to a small-format journal entirely of English papers, with an accompanying name change from China aktuell to Journal of Current Chinese Affairs. And in November 2013 the Stiftung Mercator (Mercator Foundation) announced that in the next five years it would donate 18.4 million euros to establish Europe's largest China research center, a China think tank, in Berlin, so that Germany can more effectively interact with China, the world's second largest economy, and thereby win the future.

In the universities, a move toward interdisciplinary links is already well underway. Heidelberg University has established the Karl Jaspers Centre for Advanced Transcultural Studies, part of the Cluster of Excellence "Asia and Europe in a Global Context: Shifting Asymmetries in Cultural Flows" program receiving support from the federal government. This program can receive assistance from the federal government because of its interdisciplinary, intercultural nature. In fact, all of the large clusters of excellence supported by the German government have a basic orientation toward interdisciplinary, intercultural research. This policy toward research seeks to break down the academic silos built around individual disciplines. In this way, Sinology can be integrated into an interdisciplinary framework, and in this framework develop a new significance. Changes in the framework of knowledge will hasten the demise of traditional Sinology departments and their way of conducting scholarship and, of course, further denigrate study of the classics, with its focus on the philosophical and literary literature.

In the 1990s Maren Eckhardt (b.1964) gave a prospective on the future of regional East Asian research, using developments at Ruhr University Bochum as an example. She noted three trends for future development of research on East Asia in general and China in particular: (1) German regions permeate one another. They seldom are confined to a particular sphere of research and often change. (2) Research in the regions is no longer internally motivated. Rather, it is based on global concerns and international themes. (3) 
Interdisciplinary interaction is not confined to theory, but in fact is more concerned with practical application. ${ }^{10}$ Hence, China studies must continue to decentralize and strive for mutual influence in the field.

Sinology and China studies are no longer pure research specializations. Rather, they have started to become an interdisciplinary, comprehensive research interest. The participation of German China scholars has helped to give research on China a global significance. Such research by German scholars has without doubt given scholars in China a different perspective for considering, interpreting, and criticizing China's culture and modernization. The coming of the age of globalization means that China, with one-fifth of the world's population, cannot separate itself from the world, and at the same time that it will exert a tremendous influence on the world.

10 Maren Eckhardt, "Ostasienwissenschaften an der Ruhr-Universität Bochum: Historiographische Ansätze, dargestellt am Beispiel der Chinawissenschaften" (East Asian Studies at Ruhr University Bochum: Historiographical Approaches, Illustrated by the Example of China Studies), in Chinawissenschaften - deutschsprachige Entwicklungen: Geschichte, Personen, Perspektiven (The Development of China Studies in the German Language: History, People, Perspectives), edited by Helmut Martin and Christiane Hammer (Hamburg: Institut für Asienkunde, 1999), pp.368379. Translated into Chinese as "Dongyaxue zai Luerqu Bohong Daxue: Yi Zhongguoxue wei li chanshu qi lishi yuanyuan" 东亚学在鲁尔区波鸿大学: 以中国学 为例阐述其历史洲源, in Deguo Hanxue: Lishi, fazhan, renwu yu shijiao 德国汉学: 历 史、发展、人物与视角 (Zhengzhou: Daxiang Chubanshe, 2005), pp.357-365. The relevant passage occurs on p.364 of the Chinese translation. 